- Case Videos (for display in the AATS Learning Center located in the Exhibit Hall)

Plenary and Simultaneous Session Abstracts may be submitted for the following categories:

- Adult Cardiac

- Congenital

- General Thoracic

- Perioperative Care

Case Videos may be submitted for the following categories:

- Adult Cardiac

- Congenital

- General Thoracic

Waiver of mandatory manuscript submission for publication in JTCVS may be requested at the time of submission.

The AATS is also accepting abstracts for the Allied Health Poster Competition until January 6, 2015. More details can be found at www.aats.org/annualmeeting.

\section{AATS Clinical Trials Methods Course}

October 23-25, 2014

Hyatt Regency O'Hare, Chicago, IL

The AATS is pleased to announce its inaugural AATS Clinical Trials Methods Course co-chaired by Drs David H. Harpole and Marco Zenati, October 23-25, 2014. With the continually evolving nature of clinical trials, the course will provide an intensive and interactive training program for 40 cardiothoracic surgeons across all subspecialties to acquire the critical skills and better understand the essential steps in effective clinical trial design and implementation.

The 2-and-a-half-day program will include an expert faculty of both cardiothoracic surgeons and biostatisticians who will mix didactic lectures with hands-on breakout sessions to help address the challenges in translation from "bench" to clinical protocols and level-A comparative effectiveness clinical research.

For more information and to secure your registration or housing, please visit the AATS Web site (www.aats.org).

\section{AATS Focus on Thoracic Surgery: Novel Technologies in Lung Cancer}

November 21-22, 2014

Renaissance Boston Waterfront Hotel

Boston, MA

Lung cancer is the second most common malignancy in the Western world and the most common cause of cancer-related death. Recent innovations in diagnosis, staging, and management of early stage and locally advanced non-small cell lung cancer have changed the paradigm for surgical management of lung cancer patients. A virtual explosion of technological development has enabled widespread use of minimally invasive approaches that current and future thoracic surgeons must embrace to improve the care of patients with lung cancer.

Join us in Boston once again as the AATS highlights these recent developments in its 2014 "Focus on Thoracic Surgery" program, which will focus on Novel Technologies in Lung Cancer. The faculty includes internationally recognized experts in lung cancer and application of new technology for its surgical management. We look forward to seeing you in Boston!

\section{PROGRAM COMMITTEE MEMBERS}

G. Alec Patterson, Program Director

Washington University School of Medicine

David J. Sugarbaker, Program Director

Baylor College of Medicine

Thomas A. D'Amico

Duke University Medical Center

Shaf Keshavjee

University of Toronto

James D. Luketich

University of Pittsburgh Medical Center

Bryan F. Meyers

Washington University School of Medicine

Scott J. Swanson

Brigham and Women's Hospital/Harvard Medical School

Dana Farber Cancer Institute

Course Highlights:

- Imaging and Staging

- Surgical Alternatives

- Simulation, Education, and Training

- Optimal Management of Lung Metastases

- Credentialing/Efficiencies

- Intraoperative Management

- Advanced Minimally Invasive Techniques

For more details and to register, please visit: http://aats.org/ lungcancer.

\section{AATS Grant Writing Workshop}

March 6, 2015, Bethesda, MD

Organized by the AATS Scientific Affairs and Government Relations Committee, the 2015 AATS Grant Writing Workshop will take place on Friday, March 6, 2015, at the Doubletree Bethesda in Bethesda, MD (9 miles from 
Washington, DC). This full-day program is designed for all levels of academic cardiothoracic surgeons interested in applying for grants.

The workshop will provide attendees with a better understanding of the complex nature of preparing and submitting grant proposals along with the techniques required to ensure submissions are of the highest quality. Through a didactic session, interactive panel discussions and a mock study session, attendees will work with well-known leaders in cardiothoracic surgery and NIH Staff to achieve the following:

- Create career development and training grants

- Analyze outcomes research and clinical research networks

- Assess the structure and components of a grant

- Identify extramural program and funding opportunitiesNCI and NHLBI

- Understand the steps to becoming an NIH investigator

The deadline for registration is Friday, February 6, 2013. For additional information on the workshop program, housing, and to register, please visit www.aats.org.

\section{AATS Leadership Academy Applications}

Friday, April 24, 2015, Seattle, WA

For current and future CTS Division Chiefs/Department Chairs

(Immediately prior to the AATS Annual Meeting)
The 2015 AATS Leadership Academy is an intensive, didactic, and interactive program for up to 20 surgeons who have demonstrated significant promise as potential future division chiefs or who have recently assumed the role of division chief. The goal of this program is to provide participants with the administrative, interpersonal, mentoring, and negotiating skills necessary to serve successfully as a division chief while also offering an opportunity to network with well-known thoracic surgical leaders who might subsequently serve as personal mentors after the conclusion of the program.

For additional information regarding the Academy, please visit www.aats.org. Interested applicants should meet the following qualifications before applying:

- Achieved the rank of Associate Professor

- Active/successful clinical surgeon

- Evidence of local institutional and/or state/regional leadership ability

- Evidence of academic productivity including peerreviewed publications and presentations at regional or national scientific meetings

- Funded research is preferable but not essential

Applications for consideration must be submitted electronically at www.aats.org by November 30, 2014. Participants will be selected by the Leadership Academy Committee and notified no later than February 5, 2015.

\section{The American Association for Thoracic Surgery Journals}

\section{Seminars in Thoracic and Cardiovascular Surgery}

Seminars in Thoracic and Cardiovascular Surgery Editors, Dr Harvey Pass and Dr Todd Rosengart, would like to call your attention to several articles of interest in the current issue of the journal. "The 1000th VAD, the Great Rivalry, and the Grand Experiment of the Texas Medical Center," a commentary on Dr O.H. "Bud" Frazier's 1000th VAD implantation has been co-published in the JTCVS, Texas Heart Institute Journal, and Seminars.

Paired with this commentary authored by Editor, Dr Todd Rosengart, the "News and Views" section features an editorial written by Dr Frazier providing his firsthand experience in a piece titled, "Mechanical Circulatory Assist Device Development at the Texas Heart Institute: A Personal Perspective."

These articles, as well as the Discussion in Cardiothoracic Treatment and Care on "State of the Art: CABG" moderated by Dr John Puskas and paneled by experts Drs Harold Lazar, Michael Mack, Joseph Sabik, and David Taggart, present our readers with perspectives on bilateral ITA grafting, endoscopic conduit harvesting, hybrid procedures, and the future of OPCAB.

New online: The audio recording of the Discussion is available at http://www.semthorcardiovascsurg.com/.

The last highlighted article is a "State of the Art" article by Dr Nagashree Seetharamu from New York University Cancer Center, who discusses promising immunotherapeutic strategies non-small cell lung cancer.

\section{Operative Techniques in Thoracic and Cardiovascular Surgery}

Operative Techniques in Thoracic and Cardiovascular Surgery Editor, Dr J. William Gaynor, would like to call your attention to the next issue's featured articles. We are delighted to introduce the new "Transplant Surgery" section to Op Techs. Dr Duane Davis, the Associate Editor, has invited Drs Carmelo Milano and Jonathan Chen to describe transplant surgeries following pre-transplant mechanical circulatory support as a bridge to transplant.

Dr Benjamin Kozower, Associate Editor for the "General Thoracic" section has chosen Dr Rishindra Reddy 